ORIGINAL ARTICLE

\title{
Diversity of parasitoid wasps in conventional and organic guarana (Paullinia cupana var. sorbilis) cultivation areas in the Brazilian Amazon
}

\author{
Karine SCHOENINGER ${ }^{1 *} \oplus$, Jorge L.P. SOUZA ${ }^{1,2} \odot$, Cristiane KRUG $^{3}$, Marcio L. OLIVEIRA ${ }^{1}$ \\ Instituto Nacional de Pesquisas da Amazônia - INPA, Coordenação de Biodiversidade - COBIO, Avenida André Araújo 2936, Petrópolis, CEP 69067-375 Manaus, \\ Amazonas, Brasil \\ Instituto Nacional da Mata Atlântica - INMA, Avenida José Ruschi 4, Santa Teresa, CEP 29650-000, Espírito Santo, Brasil \\ Embrapa Amazônia Ocidental, Rodovia AM-010, Km 29, Manaus, Brasil \\ * Corresponding author: karine.schoeninger@gmail.com; (D) https://orcid.org/0000-0001-9079-9570 \\ (D) https://orcid.org/0000-0003-4574-8111
}

\begin{abstract}
We surveyed parasitoid wasps (Hymenoptera) in two guarana plantations in the central Brazilian Amazon (one conventionally, and one organically managed), as well as in adjacent forest and edge areas between crop and forest. We evaluated differences between management systems in parasitoid diversity and abundance, and assessed the importance of the surrounding matrix as a source of parasitoid wasps for guarana cultivation. Parasitoid wasp richness, abundance and taxonomic composition (at family level) were compared between plantations, and among habitats within plantations. Wasps were sampled using Malaise and Moericke traps. A total of 25,951 parasitoid wasps (10,828 in the conventional, and 15,123 in the organic crop area) were collected, and were distributed in 11 superfamilies and 38 families. In the conventional management area, the greatest abundance and richness of parasitoids were recorded in the adjacent forest, while, in the organic management area, the greatest abundance and richness were recorded in the crop-forest edge. Parasitoid wasp family richness was not influenced by management system and habitat but varied significantly between trap types. Average wasp abundance varied significantly between management systems. The presence of adjacent forest in both cultivation areas likely contributed to a greater abundance and richness of parasitoid wasps, showing the importance of preserving forest areas near the plantations.
\end{abstract}

KEYWORDS: agroecosystem, Chalcidoidea, crop management, Encyrtidae, natural enemies

\section{Diversidade de vespas parasitoides em áreas de cultivo de guaraná (Paullinia cupana var. sorbilis) convencional e orgânico na Amazônia brasileira}

\section{RESUMO}

Pesquisamos vespas parasitoides (Hymenoptera) em duas plantaçóes de guaraná na Amazônia central brasileira (uma convencional e outra manejada organicamente), bem como em florestas adjacentes e áreas de borda entre cultivo e floresta. Avaliamos as diferenças entre os sistemas de manejo na diversidade e abundância de parasitoides e a importância da matriz circundante como fonte de vespas parasitoides para o cultivo de guaraná. A riqueza de vespas parasitoides, abundância e a composição taxonômica (em nível de família) foram comparadas entre as plantaçóes e entre os habitats nas plantaçóes. As vespas foram amostradas usando armadilhas Malaise e Moericke. Foram coletadas 25.951 vespas parasitoides (10.828 em área de cultivo convencional e 15.123 em cultivo orgânico), distribuídas em 11 superfamílias e 38 famílias. Na área de manejo convencional, a maior abundância e riqueza de parasitoides foi registrada na floresta adjacente, enquanto na área de manejo orgânico, a maior abundância e riqueza foram registradas na borda da floresta. A riqueza de famílias de vespas parasitoides não foi influenciada pelo sistema de manejo e habitat, mas variou significativamente entre os tipos de armadilhas. A abundância média de vespas variou significativamente entre os sistemas de manejo. A presença de floresta adjacente em ambas as áreas de cultivo provavelmente contribuiu para uma maior abundância e riqueza de vespas parasitoides, mostrando a importância de preservar as áreas florestais próximas às plantaçóes.

PALAVRAS-CHAVE: agroecossitemas, Chalcidoidea, manejo agrícola, Encyrtidae, inimigos naturais

CITE AS: Schoeninger, K.; Souza, J.L.P.; Krug, C.; Oliveira, M.L. 2019. Diversity of parasitoid wasps in conventional and organic guarana (Paullinia cupana var. sorbilis) cultivation areas in the Brazilian Amazon. Acta Amazonica 49: 283-293. 


\section{INTRODUCTION}

The complexity of the surrounding landscape and the management system employed in agricultural crops can influence the diversity of microorganisms, plants and animals present in agricultural areas (Tscharntke et al. 2005), thus affecting environmental services, such as nutrient cycling, water regulation, and biological pest control by natural enemies (Tilman et al. 2002; Kremen 2005). Parasitoid wasps are the most species-rich group of Hymenoptera in terrestrial ecosystems and are common and abundant natural enemies of insect crop pests (Sharkey 2007). They are also indicators of ecosystem health, since they are susceptible to habitat fragmentation and sensitive to ecological perturbations, specially pesticides (Kruess and Tscharntke 2000; Sharkey 2007). Conventional crop management, where increased application of fertilizers and pesticides is accompanied by the removal of native vegetation adjacent to the monoculture, has drastically reduced the presence of parasitoid wasps in this kind of environment (Altieri and Letourneau 1982). In contrast, a higher diversity of parasitoid wasps is expected in crops under organic management, where agrochemicals are not applied (Altieri and Nicholls 2004), allowing for the maintenance of a higher biodiversity in these agroecosystems (Hyvönen et al. 2003; Altieri and Nicholls 2004; Roschewitz et al. 2005).

Several management practices have been developed to increase the diversity of parasitoid wasps of agricultural pest organisms in agroecosystems (Woltz et al. 2012). For example, planting or maintaining native vegetation adjacent to plantations, even simply deploying diversely vegetated border areas, can supply additional food and refuge to insects, including natural crop-pest enemies (Landis et al. 2000) and reduce the negative impacts of agriculture on local biodiversity (Concepcion et al. 2008). Higher richness and abundance of parasitoid wasps have been observed in crops with adjacent forest when compared to crops without nearby forest (Thies and Tscharntke 1999). Studies comparing the composition of parasitoid wasp assemblages in adjacent forest and crop-area edges showed that the complexity of the agricultural landscape directly affects the presence and abundance of parasitoid wasps inside crop areas, which in turn favors the biological control of pests (Thies and Tscharntke 1999; Roschewitz et al. 2005; Woltz et al. 2012).

Guarana, Paullinia cupana var. sorbilis (Mart.) Ducke (Sapindaceae) is a species native to the Amazon region. Its natural habit is of a woody liana, but adopts the form of a semi-erect shrub when cultivated in open spaces (Castro 1992) (Supplementary Material, Figure S1). Despite its economic importance, average productivity in the state of Amazonas (Brazil) is low, at $155 \mathrm{~kg} \mathrm{ha}^{-1}$, due to rudimentary production technology and high incidence of pests, mainly the thrip Pseudophilotrips adisi (zur Strassen, 1978) (Garcia et al. 2016). Guarana in Amazonas is cultivated basically under conventional management, using herbicides and pesticides, while for the implementation of organic management, studies are still needed on bioecology, insect-plant relationships, and alternative insect-pest monitoring and control techniques (Tavares and Garcia 2009). Although the biological control of thrips by parasitoid wasps is well-established (Loomans 2006), $P$. adisi in guarana is still controlled with pesticides (Garcia et al. 2016), and little is known about the diversity of parasitoid wasps in agroecosystems in the Amazon region. As far as we know, there are no surveys of insect fauna associated with guarana crops in the Amazon region.

Considering the lack of knowledge on insects associated with Amazonian guarana plantations, and the susceptibility of this crop to pests that can be controlled by parasitoid wasps, our aim was to evaluate the diversity and abundance of parasitoid wasps in a conventional, and an organic guarana plantation in the central Amazon region of Brazil. We also sampled parasitoid wasps in adjacent forest areas and in the edge between plantations and forest in order to evaluate the role of the surrounding matrix in supplying wasps to the crop areas. Our specific goals were to estimate the similarity in parasitoid wasp richness, abundance and taxonomic composition (1) between the conventional and organic plantations; and (2) among different habitats within each guarana agroecosystem (crop area, adjacent forest and crop-forest edge).

\section{MATERIAL AND METHODS}

\section{Study area}

The study was conducted at the experimental area of EMBRAPA Amazônia Ocidental (Brazilian Agricultural Research Corporation in Western Amazonia), in Manaus, state of Amazonas, Brazil. Two experimental guarana crop areas exist at EMBRAPA, one under organic management (2 ${ }^{\circ} 53^{\prime} 29.14$ 'S, $\left.59^{\circ} 58^{\prime} 45.80^{\prime \prime} \mathrm{W}\right)$ and one under conventional management (253'42.18”S, 59 59'10.58”W) (Figure 1a). The distance between the two areas is of approximately $5 \mathrm{~km}$ and both are surrounded by secondary continuous terra firme forest (Figure 1a; Supplementary Material, Figure S1d). The edge areas of both crop areas are approximately $20 \mathrm{~m}$ wide and characterized by a dirt pathway with low plant complexity, mostly a thin herbaceous cover (Supplementary Material, Figure S1d).

The conventional management crop was established in 1996 in an area of 1.6 ha with 710 plants, and the organic management crop was established in 2003 in an area of 3.9 ha with 1.595 plants. In both areas, the guarana plants take the form of a semi erect shrub, and the spacing between plants is $5 \mathrm{~m}$ x $5 \mathrm{~m}$. Management practices followed Pereira (2005). At the beginning of this study (September 2012) the crowning of the guarana plants was carried out, i.e. the removal of weeds and the cleaning of the area within a radius of approximately $50 \mathrm{~cm}$ around the stem. At the beginning of January 2013, 

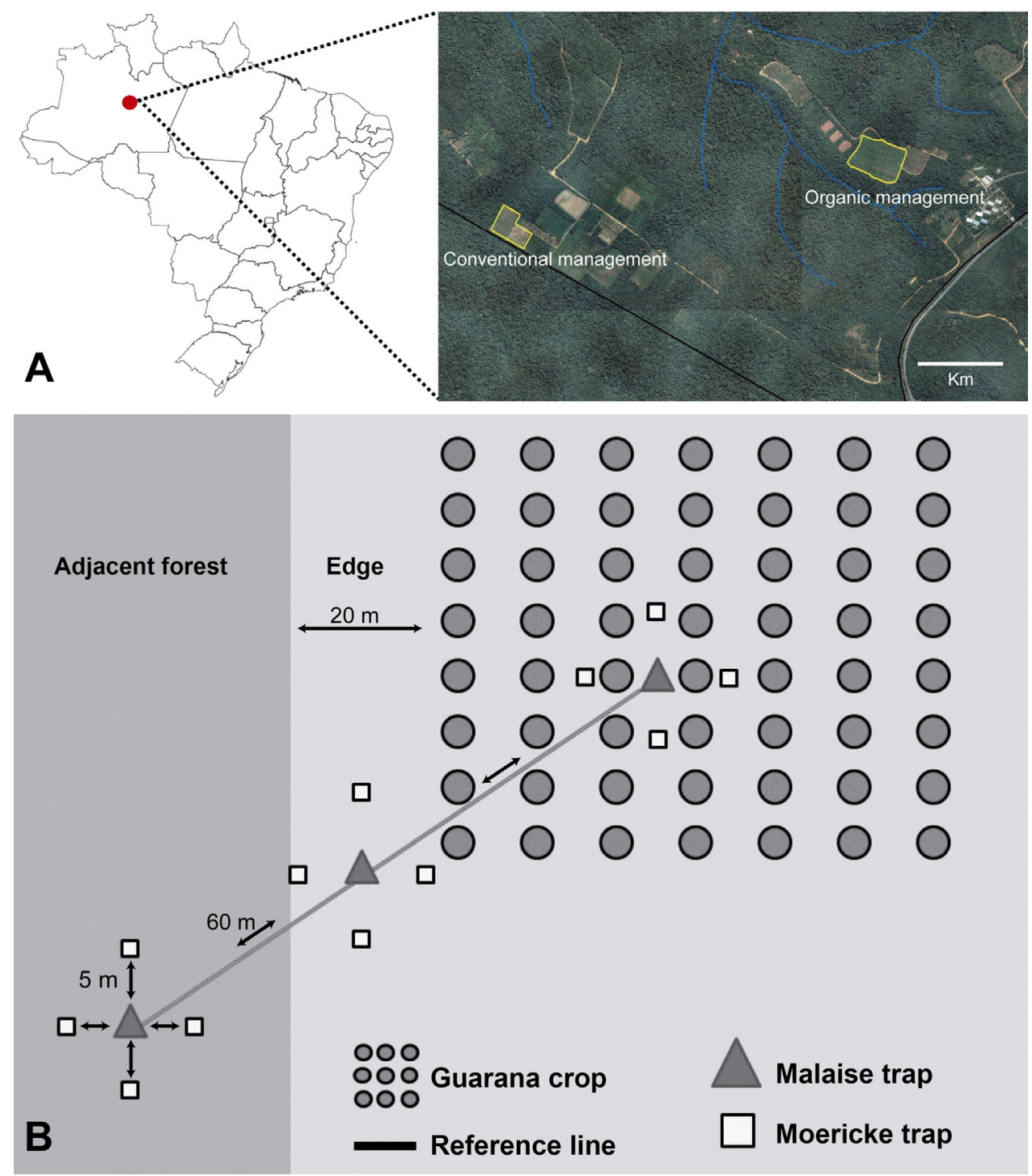

Figure 1. (A) Location of the experimental areas of conventional (left) and organic (right) guarana cultivation at Embrapa Amazônia Ocidental, in the city of Manaus, Amazonas, Brazil. Source: modified from Google maps and Google Earth; (B) Sampling design for parasitoid wasp survey in each guarana cultivation area. This figure is in color in the electronic version

a cleansing pruning was performed to remove dried, broken and diseased branches from the plants. In the conventional cultivation area an insecticide application for $P$. adisi control was carried out on January 1st, 2013 using Acephate 75\% ( $40 \mathrm{~g}$ of the commercial product diluted in $20 \mathrm{~L}$ of water).

Despite the age difference between the two crop areas, both were in the same productivity stage, which in guarana begins after the third year of planting (Castro 1992), thus we assumed that plant age would not affect parasitoid wasp presence.

\section{Sampling design}

To capture parasitoid wasps, we used Malaise and Moericke traps (Supplementary Material, Figure S1e,f), which had the best results in other wasp surveys in tropical forest (Noyes 1989). In Malaise traps (model Townes 1972) parasitoid wasps are collected in a container containing $70 \%$ alcohol located in the upper portion of the trap. The Moericke trap consisted of a yellow container $25 \mathrm{~cm}$ long x $15 \mathrm{~cm}$ wide x 5 $\mathrm{cm}$ high, containing $1000 \mathrm{ml}$ of a water solution with $2 \mathrm{ml}$ of neutral detergent.

Traps were set in groups consisting of one Malaise trap in the middle and four Moericke traps disposed in cross section around it at $5 \mathrm{~m}$ distance (Figure $1 \mathrm{~b}$ ). Each of these groups was considered a sampling point. At each sampling point, we considered the four Moericke traps as a single sampling unit, so their samples were added up for analyses. In each area, 
one sampling point was installed in each habitat (crop area, forest-crop edge, and adjacent forest) along a line with $60 \mathrm{~m}$ distance between points (Figure 1b), totaling six sampling points overall.

Sampling occurred every two weeks from September 2012 to February 2013, totaling 12 samplings. On each sampling occasion, the traps remained in the area for four days. Water of all Moericke traps was replaced every 24 hours in order to avoid loss and/or deterioration of biological material.

\section{Taxonomic identification}

The parasitic Hymenoptera and some Aculeata families (Vespoidea + Apoidea, excluding Formicidae and Apidae s.l) were sorted out from the collected material in the Hymenoptera Laboratory of Instituto Nacional de Pesquisas da Amazônia (INPA). Parasitoid wasps were identified to the family level using the identification keys of Goulet and Huber (1993) and Fernández and Sharkey (2006). The identifications were standardized according to Aguiar et. al. (2013). The most abundant genera of Encyrtidae were identified using the identification key of Noyes (1980). The vouchers were deposited at INPA's Invertebrate (Insecta) collection.

\section{Data analysis}

We determined family richness (number of families) and parasitoid wasp abundance (number of individuals) at each sampling point, for the Malaise trap and the joint data of the four Moericke traps. We used analysis of variance (ANOVA) for repeated measures (Crowder and Hand 1990; Davis 2002; Gotelli and Ellison 2004) to compare family richness and abundance between crop management types, among habitats, and between trap types. The interaction between time and sample groups was included in the model. When required, ANOVA was followed by a post hoc Tukey multiple-range test (Yandell 1997). The dimensionality of data on parasitoid wasp abundance was reduced using Nonmetric Multidimensional Scaling (NMDS) (Minchin 1987) based on the Bray-Curtis dissimilarity index.

We used a Mantel test (Mantel 1967) to analyze the similarity in parasitoid-wasp family composition between management systems, among habitats and between sampling methods. The Mantel test was conducted with the Pearson correlation coefficient with 1000 permutations at $\mathrm{p} \leq 0.05$. All analyses were conducted in the $\mathrm{R}$ environment for statistical computing, version 3.3.1 (R Core Team 2016), using the Vegan package (Oksanen et al. 2016).

\section{RESULTS}

A total of 25,951 parasitoid wasps were collected, that belonged to 11 superfamilies and 38 families. The most abundant superfamilies were Chalcidoidea and Platygastroidea, with over $65 \%$ of the total parasitoids collected in both study areas. Encyrtidae, Platygastridae, Diapriidae, Mymaridae and Eulophidae were the families with the highest number of individuals (Table 1). In the conventional management area, 10,828 individuals were collected, belonging to 10 superfamilies and 35 families. In the organic management area, abundance was higher with 15,123 individuals from 11 superfamilies and 37 families. Encyrtidae was abundant in both the edge and the interior of the crop in both management systems, having as main representatives Copidosoma sp. and Neodusmetia sangwani (Subba Rao, 1957), while Platygastridae was the most abundant in the forest in both areas. In total, 34 families were common to the organic and conventional management areas (Table 1). Gasteruptiidae, Leucospidae and Stephanidae were recorded only in the organic management area, while Ampulicidae was recorded only in the conventional management area. In the conventional management area, the highest abundance and richness of families was recorded in the forest, with 4,395 individuals and 34 families. In the organic management area, the highest abundance and richness occurred in the crop-forest edge, with 7,738 individuals and 35 families.

A total of 37 families were sampled using the Malaise trap, and 30 families using the Moericke traps, and 29 families were common to both traps (Table 2). Malaise and Moericke traps had a similar composition of parasitoid families in conventional management, while in organic management the composition tended to differ between the traps. The Malaise trap captured groups of Hymenoptera that were not collected with Moericke traps, such as Gasteruptiidae, Leucospidae, Megaspilidae, Perilampidae, Liopteridae, Sclerogibbidae, Stephanidae, and Tanaostigmatidae. Moericke traps were particularly efficient collecting Encyrtidae, Platygastridae and Ceraphronidae.

Average family richness in the Malaise trap was significantly higher than the richness detected in Moerike traps (Figure 2; Table 3). Management system and habitat did not affect family richness. The interaction with time was non-significant for all analyzed factors, showing that there was no significant trend in wasp capture rates by family over time regarding crop management, habitat or sampling method (Table 3). Organic management had a higher average abundance of parasitoid families than conventional management (Tukey post hoc test $\mathrm{p}<0.01$ ) (Figure 3a). Similarly, the edge area had a greater abundance than the crop and forest environments (Tukey post hoc test $p<0.05$ ) (Figure 3b). Abundance also varied over time, as sample 4 (October 2012) was significantly larger than sample 12 (February 2013) (Tukey post hoc test $\mathrm{p}<0.01$ ) (Figure 3c).

In the conventional management area, there was about $40 \%$ similarity in family composition using Malaise traps between crop-forest edge and crop, and about $50 \%$ similarity among the three habitats using Moerike traps (Figure 4a,b; 
Table 1. Number of parasitoid wasps sampled in two guarana crop areas (under conventional and organic management) in the state of Amazonas (Brazilian Amazon) sampled in three different habitats (within the crop area, in the cropforest edge, and in adjacent forest)

\begin{tabular}{|c|c|c|c|c|c|c|c|c|}
\hline \multirow{2}{*}{ Superfamily/Family } & \multicolumn{4}{|c|}{ Conventional } & \multicolumn{4}{|c|}{ Organic } \\
\hline & Forest & Edge & Crop & Total & Forest & Edge & Crop & Total \\
\hline \multicolumn{9}{|l|}{ Apoidea } \\
\hline Ampulicidae & 0 & 2 & 1 & 3 & 0 & 0 & 0 & 0 \\
\hline Crabronidae & 37 & 54 & 106 & 197 & 21 & 96 & 56 & 173 \\
\hline Sphecidae & 3 & 25 & 12 & 40 & 1 & 19 & 9 & 29 \\
\hline \multicolumn{9}{|l|}{ Ceraphronoidea } \\
\hline Ceraphronidae & 166 & 159 & 130 & 455 & 224 & 268 & 233 & 725 \\
\hline Megaspilidae & 1 & 0 & 0 & 1 & 1 & 1 & 0 & 2 \\
\hline \multicolumn{9}{|l|}{ Chalcidoidea } \\
\hline Agaonidae & 2 & 1 & 8 & 11 & 0 & 43 & 2 & 45 \\
\hline Aphelinidae & 71 & 93 & 84 & 248 & 53 & 218 & 152 & 423 \\
\hline Chalcididae & 28 & 45 & 73 & 146 & 5 & 176 & 114 & 295 \\
\hline Encyrtidae & 225 & 877 & 1611 & 2,713 & 342 & 2484 & 1020 & 3,846 \\
\hline Eucharitidae & 2 & 5 & 4 & 11 & 0 & 18 & 10 & 28 \\
\hline Eulophidae & 248 & 72 & 143 & 463 & 133 & 323 & 536 & 992 \\
\hline Eupelmidae & 46 & 13 & 3 & 62 & 3 & 16 & 12 & 31 \\
\hline Eurytomidae & 13 & 3 & 5 & 21 & 5 & 23 & 28 & 56 \\
\hline Leucospidae & 0 & 0 & 0 & 0 & 0 & 1 & 0 & 1 \\
\hline Mymaridae & 224 & 132 & 155 & 511 & 218 & 512 & 343 & 1,073 \\
\hline Perilampidae & 5 & 4 & 2 & 11 & 0 & 20 & 15 & 35 \\
\hline Pteromalidae & 129 & 25 & 17 & 171 & 62 & 69 & 50 & 181 \\
\hline Signiphoridae & 31 & 18 & 12 & 61 & 12 & 34 & 16 & 62 \\
\hline Tanaostigmatidae & 6 & 0 & 1 & 7 & 0 & 1 & 0 & 1 \\
\hline Torymidae & 14 & 5 & 5 & 24 & 3 & 5 & 2 & 10 \\
\hline Trichogrammatidae & 60 & 51 & 64 & 175 & 23 & 96 & 67 & 186 \\
\hline \multicolumn{9}{|l|}{ Chrysidoidea } \\
\hline Bethylidae & 395 & 177 & 121 & 693 & 360 & 162 & 108 & 630 \\
\hline Chrysididae & 19 & 26 & 8 & 53 & 1 & 5 & 2 & 8 \\
\hline Dryinidae & 54 & 11 & 143 & 208 & 75 & 21 & 21 & 117 \\
\hline Sclerogibbidae & 3 & 0 & 0 & 3 & 2 & 0 & 0 & 2 \\
\hline \multicolumn{9}{|l|}{ Cynipoidea } \\
\hline Figitidae & 119 & 15 & 11 & 145 & 76 & 129 & 77 & 282 \\
\hline Liopteridae & 4 & 0 & 0 & 4 & 2 & 0 & 0 & 2 \\
\hline
\end{tabular}

\section{Diaprioidea}

\begin{tabular}{lcccccccc}
\hline Diapriidae & 365 & 182 & 133 & $\mathbf{6 8 0}$ & 398 & 637 & 225 & $\mathbf{1 , 2 6 0}$ \\
\hline Evanioidea & & & & & & & & \\
\hline Evaniidae & 139 & 31 & 21 & $\mathbf{1 9 1}$ & 81 & 107 & 61 & $\mathbf{2 4 9}$ \\
Gasteruptiidae & 0 & 0 & 0 & $\mathbf{0}$ & 0 & 1 & 1 & $\mathbf{2}$ \\
\hline Ichneumonoidea & & & & & & & & \\
\hline Braconidae & 314 & 90 & 92 & $\mathbf{4 9 6}$ & 216 & 312 & 202 & $\mathbf{7 3 0}$ \\
\hline Ichneumonidae & 148 & 52 & 59 & 259 & 90 & 128 & 79 & $\mathbf{2 9 7}$ \\
\hline Platygastroidea & & & & & & & & \\
\hline Platygastridae & 1.161 & 546 & 533 & $\mathbf{2 , 2 4 0}$ & 1.034 & 1.299 & 651 & $\mathbf{2 , 9 8 4}$ \\
\hline Stephanoidea & & & & & & & & \\
\hline Stephanidae & 0 & 0 & 0 & $\mathbf{0}$ & 0 & 1 & 0 & $\mathbf{1}$ \\
\hline Vespoidea & & & & & & & & \\
\hline Mutillidae & 172 & 4 & 3 & $\mathbf{1 7 9}$ & 25 & 6 & 7 & $\mathbf{3 8}$ \\
\hline Pompilidae & 167 & 75 & 27 & $\mathbf{2 6 9}$ & 46 & 94 & 41 & $\mathbf{1 8 1}$ \\
Rhopalosomatidae & 2 & 5 & 2 & $\mathbf{9}$ & 1 & 1 & 3 & $\mathbf{5}$ \\
\hline Tiphiidae & 22 & 13 & 33 & $\mathbf{6 8}$ & 31 & 52 & 58 & $\mathbf{1 4 1}$ \\
\hline Total & 4,395 & 2,811 & 3,622 & 10,828 & 3,544 & 7,378 & 4,201 & 15,123 \\
\hline
\end{tabular}

Table 2. Total number of parasitoid wasps sampled per family with Malaise and Moericke traps in two guarana crop areas (under conventional and organic management) in the state of Amazonas (Brazilian Amazon) and in different habitats in each area (within the crop, in the crop-forest edge and in adjacent forest).

\begin{tabular}{llllll}
\hline \multirow{2}{*}{ Superfamily/Family } & \multicolumn{3}{c}{ Moericke } & & \multicolumn{3}{c}{ Malaise } \\
\cline { 2 - 3 } \cline { 5 - 6 } & Forest & Edge Crop & Forest & Edge Crop \\
\hline
\end{tabular}

\begin{tabular}{|c|c|c|c|c|c|c|}
\hline Apoidea & & & & & & \\
\hline Ampulicidae & 0 & 2 & 1 & 0 & 0 & 0 \\
\hline Crabronidae & 23 & 52 & 62 & 35 & 98 & 100 \\
\hline Sphecidae & 1 & 0 & 2 & 3 & 44 & 19 \\
\hline \multicolumn{7}{|l|}{ Ceraphronoidea } \\
\hline Ceraphronidae & 325 & 381 & 330 & 65 & 46 & 33 \\
\hline Megaspilidae & 0 & 0 & 0 & 2 & 1 & 0 \\
\hline \multicolumn{7}{|l|}{ Chalcidoidea } \\
\hline Agaonidae & 0 & 4 & 5 & 2 & 40 & 5 \\
\hline Aphelinidae & 82 & 171 & 183 & 42 & 140 & 53 \\
\hline Chalcididae & 3 & 11 & 9 & 30 & 210 & 178 \\
\hline Encyrtidae & 467 & 2,085 & 2,219 & 100 & 1,276 & 412 \\
\hline Eucharitidae & 0 & 2 & 2 & 2 & 21 & 12 \\
\hline Eulophidae & 115 & 73 & 123 & 266 & 322 & 556 \\
\hline Eupelmidae & 13 & 11 & 7 & 36 & 18 & 8 \\
\hline Eurytomidae & 1 & 0 & 2 & 17 & 26 & 31 \\
\hline Leucospidae & 0 & 0 & 0 & 0 & 1 & 0 \\
\hline Mymaridae & 249 & 281 & 328 & 193 & 363 & 170 \\
\hline Perilampidae & 0 & 0 & 0 & 5 & 24 & 17 \\
\hline Pteromalidae & 142 & 29 & 0 & 49 & 65 & 63 \\
\hline Signiphoridae & 21 & 31 & 22 & 22 & 21 & 6 \\
\hline Tanaostigmatidae & 0 & 0 & 0 & 6 & 1 & 1 \\
\hline Torymidae & 5 & 2 & 0 & 12 & 8 & 7 \\
\hline Trichogrammatidae & 31 & 105 & 114 & 52 & 42 & 17 \\
\hline
\end{tabular}

\section{Chrysidoidea}

\begin{tabular}{|c|c|c|c|c|c|c|}
\hline Bethylidae & 39 & 33 & 24 & 716 & 306 & 205 \\
\hline Chrysididae & 5 & 17 & 0 & 15 & 14 & 10 \\
\hline Dryinidae & 53 & 10 & 0 & 76 & 22 & 164 \\
\hline Sclerogibbidae & 0 & 0 & 0 & 5 & 0 & 0 \\
\hline \multicolumn{7}{|l|}{ Cynipoidea } \\
\hline Figitidae & 21 & 32 & 27 & 174 & 112 & 61 \\
\hline Liopteridae & 0 & 0 & 0 & 6 & 0 & 0 \\
\hline \multicolumn{7}{|l|}{ Diaprioidea } \\
\hline Diapriidae & 412 & 195 & 109 & 351 & 624 & 249 \\
\hline \multicolumn{7}{|l|}{ Evanioidea } \\
\hline Evaniidae & 26 & 7 & 3 & 194 & 131 & 79 \\
\hline Gasteruptiidae & 0 & 0 & 0 & 0 & 1 & 1 \\
\hline \multicolumn{7}{|l|}{ Ichneumonoidea } \\
\hline Braconidae & 122 & 73 & 49 & 408 & 329 & 245 \\
\hline Ichneumonidae & 134 & 68 & 17 & 104 & 112 & 121 \\
\hline \multicolumn{7}{|l|}{ Platygastroidea } \\
\hline Platygastridae & 1,288 & 975 & 710 & 907 & 870 & 474 \\
\hline \multicolumn{7}{|l|}{ Stephanoidea } \\
\hline Stephanidae & 0 & 0 & 0 & 0 & 1 & 0 \\
\hline \multicolumn{7}{|l|}{ Vespoidea } \\
\hline Mutillidae & 2 & 3 & 3 & 195 & 7 & 7 \\
\hline Pompilidae & 55 & 53 & 22 & 158 & 116 & 46 \\
\hline Rhopalosomatidae & 0 & 0 & 4 & 3 & 6 & 5 \\
\hline Tiphiidae & 7 & 16 & 31 & 46 & 49 & 60 \\
\hline Total & 3,642 & 4,722 & 4,408 & 4,297 & 5,467 & 3,415 \\
\hline
\end{tabular}




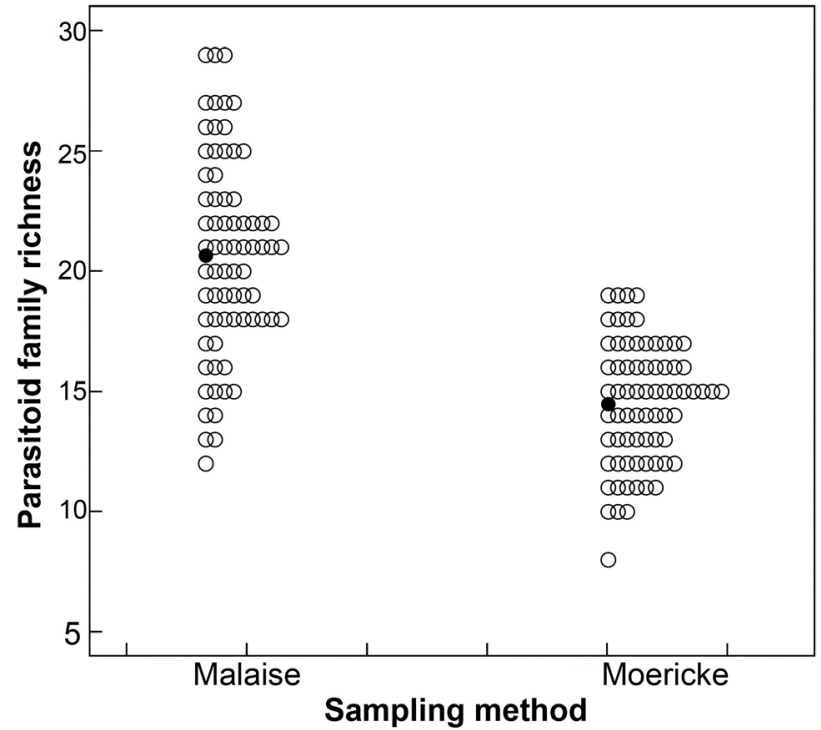

Figure 2. Parasitoid wasp family richness recorded using Malaise and Moericke traps at six sampling points replicated biweekly (12 sampling occasions) between September 2012 and February 2013 in two guarana cultivation areas in the central Brazilian Amazon. Black circles represent the average values; equal values are shown side by side.

Table 3. Results of analysis of variance of repeated measures for parasitoid wasp family richness and abundance in two guarana plantations in the central Brazilian Amazon, comparing crop management types (conventional and organic), habitats (within the crop, crop-forest edge, and adjacent forest), and sampling methods (Malaise and Moericke traps) and their interaction with samples over time.

\begin{tabular}{lccc}
\hline Variables/factors & $\begin{array}{c}\text { Degrees of } \\
\text { freedom }\end{array}$ & F value & p value \\
\hline Parasitoid wasp family richness & & & \\
Crop management types & 1 & 3.89 & 0.0516 \\
\hline Sampling habitats & 2 & 2.80 & 0.0662 \\
\hline Sampling methods & 1 & 108.89 & $<0.001$ \\
\hline Samples (over time) & 11 & 15.71 & 0.1223 \\
\hline Interaction time x crop management type & 11 & 0.59 & 0.8296 \\
\hline Interaction time x habitats & 22 & 0.30 & 0.9986 \\
\hline Interaction time x sampling methods & 11 & 0.62 & 0.8053 \\
\hline Parasitoid wasp family abundance & & & \\
\hline Crop management types & 1 & 12.864 & $<0.001$ \\
\hline Sampling habitats & 2 & 3.727 & $<0.05$ \\
\hline Sampling methods & 1 & 0.116 & 0.7346 \\
\hline Samples (over time) & 11 & 2.092 & $<0.05$ \\
\hline Interaction time x crop management type & 11 & 0.817 & 0.6228 \\
\hline Interaction time x habitats & 22 & 0.193 & 0.9999 \\
\hline Interaction timex sampling methods & 11 & 0.366 & 0.9657 \\
\hline
\end{tabular}

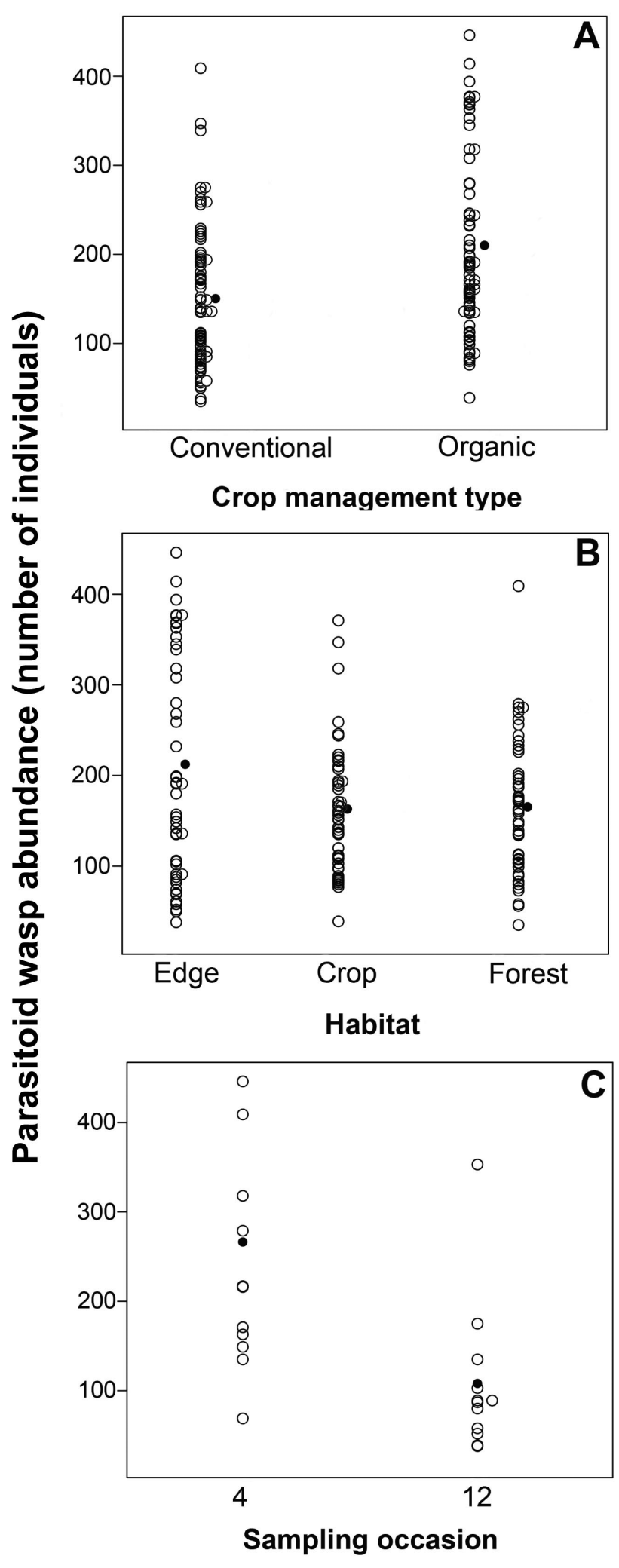

Figure 3. Abundance of parasitoid wasp families in two guarana plantation areas in the central Brazilian Amazon compared between plantation management types (A), among habitat types (B), and between sampling occasions (C). Black dots are average values. Only the two significantly different sampling occasions are shown. 

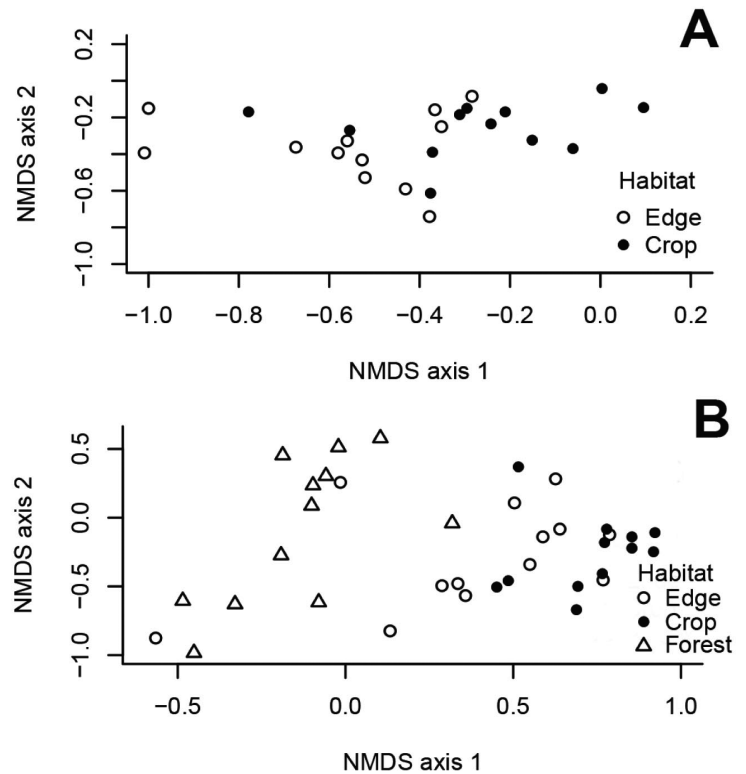

NMDS axis 1
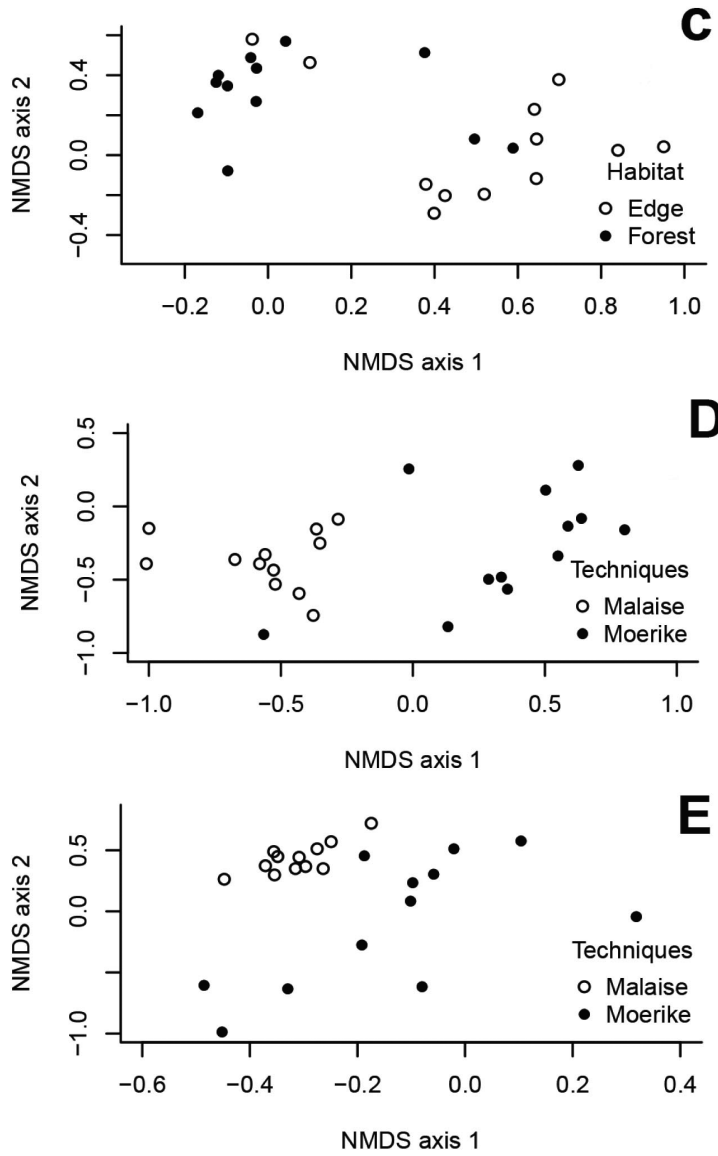

Figure 4. NMDS ordinations indicating similarities in the data on parasitoid wasp family abundance in two guarana plantation areas in the central Brazilian Amazon: (A) between crop and forest-crop edge sampled with Malaise traps in the conventional plantation; (B) among crop, forest-crop edge and forest sampled with Moericke traps in the conventional plantation; (C) among crop-forest edge and forest in the organic plantation; (D) between Malaise and Moericke traps in crop-forest edge in the conventional plantation; and (E) between Malaise and Moericke traps in adjacent forest in the conventional plantation.
Table 4. Mantel coefficients for parasitoid wasp family composition comparison among sampled habitats (crop area, crop-forest edge, adjacent forest) and between sampling methods (Malaise and Moericke traps) in two guarana crop areas managed conventionally and as an organic culture in the central Brazilian Amazon. Significance levels $p \leq 0.05^{*} ; p<0.01^{* *} ; p<0.001^{* * *}$.

\begin{tabular}{lccc}
\hline & Comparison & Conventional & Organic \\
\hline \multirow{2}{*}{ Malaise } & Crop-Edge & $0.4230^{*}$ & 0.2234 \\
& Edge - Forest & 0.1337 & 0.2083 \\
& Crop -Forest & 0.1509 & 0.2725 \\
\hline \multirow{2}{*}{ Moericke } & Crop-Edge & $0.4659^{* *}$ & 0.0045 \\
& Edge - Forest & $0.5155^{* *}$ & $0.7576^{* * *}$ \\
\hline Edge & Crop -Forest & $0.4782^{* *}$ & 0.0159 \\
\hline Forest & Malaise-Moericke & $0.3320^{*}$ & 0.0536 \\
\hline Crop & Malaise-Moericke & $0.5514^{* * *}$ & 0.0874 \\
\hline & Malaise-Moericke & 0.1376 & 0.2204 \\
\hline
\end{tabular}

Table 4). In the organic management area, family composition with Moerike traps showed the highest similarity (above 75\%) between crop-forest edge and forest (Figure 4c; Table 4). Composition was significantly similar between sampling methods in the crop-forest edge and forest (Figure 4d,e; Table 4 ) in the conventional management area. In the crop and in all habitats in the organic management area, composition tended to be significantly different (Table 4).

\section{DISCUSSION}

Surveys of parasitoid wasps are scarce in Brazilian agroecosystems (Perioto et al. 2002a), specially in Amazonia. According to Pinheiro-Machado et al. (2002) although the Amazon forest comprises one of the highest biodiversities world-wide, no extensive survey of parasitoid wasp diversity has been conducted in the region. Our study was the first to assess the parasitoid wasp fauna within guarana plantations in Amazonas state. We detected high family richness and relatively high abundance of parasitoid wasps when compared to other crop systems in Brazil (Table 5). The majority of studies conducted elsewhere in Brazil recorded 21-24 families, except for the study of Perioto et al. (2002a). However, the data in Table 5 has to be compared with caution regarding the variation in the taxonomical coverage of parasitoid classification adopted in different studies, as well as the variability in sampling design, methods and effort, and also the variation in environments sampled, which likely increases parasitoid richness estimates (Nakayama et al. 2008). The high abundance and richness found in our study was probably due to a greater diversity of parasitoid wasps in the Amazon rainforest, where habitat complexity and availability of several vegetation strata can improve the availability of microhabitats and resources for this group of wasps, and which has huge 
untapped potential for the detection of species that can be used in biological control (Sperber et al. 2004).

The richness and abundance of native plants and animals tends to decrease in agricultural landscapes that are more disturbed by pesticides, soil management, and landscape uniformity (Pfiffner and Luka 2000). Contradicting expectations, we did not detect differences in parasitoid wasp family richness between conventional and organic management. This may be in part due to that there was no pesticide application in the conventional crop until the second-to-last sampling. We also did not find differences in parasitoid wasp family richness between crops and adjacent habitats. According Anderson et al. (2012) adjacent habitats have higher invertebrate abundance and richness of taxa than agricultural productive fields, as they provide potential refuge and food resources for non-pest herbivorous insects and predatory and parasitoid arthropods. However, a single plant species can also support a high diversity of arthropods (Siemann 1998; Siemann et al. 1998), as is the case of guarana, especially in its flowering period, which favours a high richness of herbivorous invertebrates and associated pollinators (Schultz and Valois 1974; Escobar et al. 1984; Krug et al. 2015). Thus, the presence of these herbivorous invertebrates in guarana may be an attraction for parasitoid wasps present in adjacent habitats. In addition, unlike other annual short-cycle crops, guarana is characterized by being a stable perennial crop, without drastic changes in vegetation, which can provide a favorable environment for the presence of invertebrates, including parasitoid wasps (Werling et al. 2011).

Parasitoid wasp abundance was consistently higher in the organic plantation. This may have been related to the effects of management practices (Puech et al. 2014). In the organic management, the presence of vegetation between the lines of cultivation was much more pronounced than in the conventional management, which may have favored the greater presence of hosts, food resources or refuges for parasitoid wasps.

Encyrtidae was the most abundant family both in the organic and conventional guarana plantation. The dominance of Encyrtidae in crop areas was due to the presence of Copidosoma sp. and Neodusmetia sangwani, which was registered in other regions in Brazil. Copidosoma sp. represented $94 \%$ of Encyrtidae sampled in cotton crops in southeastern Brazil (Perioto et al. 2002a). Neodusmetia sangwani was introduced in Brazil in 1967 for controlling the mealybug Antonina graminis Maskell, 1897 (Santos 1976), which has been kept below the level of economic damage as a result of the action of this parasitoid (Batista-Filho et al. 2017). Neodusmetia sangwani was probably introduced in Amazonas through releases for the control of A. graminis (Filho and Silva 1988).

The higher abundance of Platygastridae in the forest (conventional management) and crop-forest edges and forest (organic management) may be related to a source-sink dynamic between the forest and the crop area. Adults of this group are found in many habitats, usually in the canopy, in search of their hosts, that belong to Cecidomyiidae (Diptera) (Masner and Aryas-Pena 2007). Platygastridae are widely distributed and very common, as the family contains approximately 78 genera with 1,100 species described world-wide, and 33 genera and 78 species in the Neotropical region (Arias 2002).

Although the analysis at family level may be confounded by pooling diverse species, with different habits and behaviors, a study in cacao farms showed that richness of parasitoid wasp families (Ichneumonidae, Braconidae and Chalcididae) had the same sensitivity as species richness to detect nearlysignificant differences in the conservation value of farms (Mazon 2016). When using higher taxonomic levels to infer

Table 5. Abundance and richness of parasitoid wasp families in different agricultural crops in Brazil, showing the sampling method used and the taxonomic classification adopted.

\begin{tabular}{|c|c|c|c|c|c|}
\hline Crop & Abundance & Richness & Sampling method & Classification & Source \\
\hline $\begin{array}{l}\text { Watermelon (Citrullus lanatus (Thunb.) } \\
\text { Matsum. \& Nakai) }\end{array}$ & 3,123 & 24 & Moericke, McPhail and Pitfall & $\begin{array}{l}\text { Parasitic + Symphyta + Aculeta } \\
\text { (Vespoidea + Apoidea) }\end{array}$ & Costa et al. (2016) \\
\hline Tobacco (Nicotiana tabacum L.) & 1,047 & 36 & Malaise, Moericke and Pitfall & Parasitic + Aculeata (Vespoidea) & Dorfey et al. (2011) \\
\hline Appletree (Malus domestica Borkh.) & 1,249 & 25 & Malaise & Parasitic + Aculeata (Vespoidea) & Klesener et al. (2013) \\
\hline Citrus (Citrus sinensis (L.) Osbeck) & 5,148 & 36 & Moericke, Malaise and Pitfall & $\begin{array}{l}\text { Parasitic + Symphyta + Aculeta } \\
\text { (Vespoidea + Apoidea) }\end{array}$ & Lara et al. (2015) \\
\hline Cacao (Theobroma cacao L.) & 9,700 & 30 & $\begin{array}{l}\text { Malaise trap designs (yellow } \\
\text { intercept, duplicated width } \\
\text { and bottom addition) }\end{array}$ & Parasitica and Chrysidoidea & Nakayama et al. (2008) \\
\hline Cotton (Gossypium hirsutum L.) & 16.166 & 22 & Moericke & Parasitica and Chrysidoidea & Perioto et al. (2002a) \\
\hline Soybean (Glycine max (L.) Merril) & 4,969 & 15 & Moericke & Parasitica and Chrysidoidea & Perioto et al. (2002b) \\
\hline Coffee (Coffea arabica L.) & 5,228 & 21 & Moericke & Parasitica and Chrysidoidea & Perioto et al. (2004) \\
\hline Coffee (Coffea arabica L.) organic & 4,817 & 26 & Moericke (yellow pan traps) & Parasitic + Aculeata (Vespoidea) & Ferreira et al. (2013) \\
\hline $\begin{array}{l}\text { Guaraná (Paullinia cupana var. sorbilis } \\
\text { (Mart.) Ducke) }\end{array}$ & 25,951 & 38 & Malaise and Moericke & $\begin{array}{l}\text { Parasitica + Aculeata (Vespoidea } \\
+ \text { Apoidea - Apidae s.l.) }\end{array}$ & Present study \\
\hline
\end{tabular}


diversity patterns, care must be taken with the choice of groups, which must be taxonomically well-resolved, easily recognized, and have species that share a similar biology (Caro and O'Doherty 1999). Thus, studies to identify surrogate taxa to accurately evaluate the richness and patterns of distribution of parasitoid wasps in crops should be prioritized, specially in Amazonia, where there is a high proportion of unidentified biodiversity and insufficient resources for large-scale collection and identification to species level. Furthermore, hymenopteran parasitoids are considered good biodiversity indicators, not only because of their high species richness, but also because of their position in the food chain, so that their diversity may reflect the diversity of the lower trophic levels, and they can even be used as a proxy for the diversity of other taxa (Anderson et al. 2012).

One of the most frequent questions in comparative studies of parasitoid wasp diversity concerns the best methods for obtaining a representative sample from a given area (Noyes 1989; Perioto et al. 2004), which tends to depend on habitat structure and the group of parasitoid wasps being studied (Mazón and Bordera 2008). In order to maximize sampling efficiency of hymenopteran parasitoid communities, location, trap size and extension of the area to be sampled are taken into account, but the best results are achieved when different methods are combined (Fraser et al. 2008; Mazón and Bordera 2008), which increases the chances of sampling all potential niches (Longino et al. 2002).

In our study, we considered that the Malaise trap had excellent results, and the Moericke trap, satisfactory results. Yet, the combined use of Malaise and Moericke traps in Amazonian agroforestry areas made the samples more representative in terms of richness and abundance of parasitoid wasps. However, Malaise traps should be prioritized when time and/or budget are constrained, as they do not depend on attraction but on interception, so that all insects flying near ground have the same probability of being sampled in areas where the canopy level is not very high.

\section{CONCLUSIONS}

Richness of parasitoid wasps at the family level did not vary significantly in guarana plantations managed conventionally and organically in central Amazonia, possibly due to that pesticides were not applied to the conventional plantation during most of the sampling period. However, parasitoid abundance was significantly higher in the organic plantation and in adjacent forest and forest-crop edge habitats. The presence of more dense and structured vegetation in between guarana plants in the organic plantation probably influenced this result. It seems important to grow crops near native forest, given the activity of the parasitoid wasps in both environments. Native forest areas characterized by higher plant diversity likely have a greater abundance of food resources and shelter availability for parasitoid wasps. Malaise traps were the most efficient sampling methods to collect a great number of families and abundance of parasitoid wasps. Nonetheless, the Moericke traps were a useful complementary method, since certain families were collected at a higher abundance in these traps. Our survey forms a basis for further studies aiming at the use of surrogate higher-level taxa instead of species level to evaluate and monitor diversity and distribution of parasitoid wasps in guarana crops, as well as the applied use of hymenopteran parasitoids in programs of integrated pest management in Amazonian crops.

\section{ACKNOWLEDGMENTS}

This study was financed in part by Coordenaçáo de Aperfeiçoamento de Pessoal de Nível Superior (CAPES), Brasil - Finance Code 001. We thank Embrapa Amazônia Ocidental for making their experimental guarana plantations available for this study and for all the support provided. J.L.P.S. was supported by Conselho Nacional de Desenvolvimento Científico e Tecnológico (CNPq) through post-doctoral scholarship \# 302301/2019-4. MLO is thankful for the CNPq productivity bursary, Brazil (306100/2016-9). Adrian Barnett helped with the English. We also thank the reviewers of a previous version for their comments on the manuscript.

\section{REFERENCES}

Aguiar, A.P.; Deans, A.R.; Engel, M.S.; Forshage, M.; Huber, J.T.; Jennings, J.T.; et al. 2013. Order Hymenoptera. Zootaxa, 3703: 051-062.

Altieri, M.A.; Letourneau, D.K. 1982. Vegetation management and biological control in agroecosystems. Crop Protection, 1: 405-430.

Altieri, M.; Nicholls, C.I. 2004. Biodiversity and Pest Management in Agroecosystems. Food Products Press ${ }^{\oplus}$, New York, 252p.

Anderson, A.; Carnus, T.; Helden, A.J.; Sheridan, H.; Purvis, G. 2012. The influence of conservation field margins in intensively managed grazin land on communities of five arthropod trophic groups. Insect Conservation and Diversity, 6: 201-211.

Arias, T.M. 2002. Lista de los géneros y especies de la superfamilia Platygastroidea (Hymenoptera) de la Región Neotropical. Biota Colombiana 3: 215-234.

Batista-Filho, A.; Costa, V.; Hojo, H. 2017. Neodusmetia sangwani (Subba Rao) (Hymenoptera: Encyrtidae) to control Antonina graminis (Maskell) (Hemiptera: Pseudococcidae) in pastures in Brazil: a revision. Arquivos do Instituto Biológico, 84: e0432016.

Caro, T.M.; O’Doherty, G. 1999. On the use of surrogate species in conservation biology. Conservation Biology, 13: 805-814

Castro, N.H.C. 1992. Cultura do Guaranazeiro. Embrapa-CPATU, Belém, 71p.

Concepcion, E.D.; Diaz, M.; Baquero, R.A. 2008. Effects of landscape complexity on the ecological effectiveness of agrienvironment schemes. Landscape Ecology, 23: 135-148.

Costa, E.M.; Araújo, E.L.; Fernandes, D.R.R.; Silva, P.A.F.; Sales Júnior, R. 2016. Diversidade e métodos de amostragem de 
Hymenoptera na cultura da melancia no semiárido. Horticultura Brasileira 34: 257-264.

Crowder, M.J.; Hand, D.J. 1990. Analysis of Repeated Measures. CRC Press, 272p.

Davis, C. 2002. Statistical Methods for the Analysis of Repeated Measurements. Springer, New York, 417p.

Dorfey, C.; Schoeninger, K.; Köhler, A. 2011. Levantamento das famílias de himenópteros parasitoides associados ao cultivo de tabaco (Nicotiana tabacum L.) em Santa Cruz do Sul e Lagoão, Rio Grande do Sul, Brasil. Arquivos do Instituto Biológico, 78: 449-451.

Escobar, J.R.; Corrêa, M.P.F.; Aguilera, F.P. 1984. Estruturas florais, floração e técnicas para a polinização controlada do guaranazeiro. Pesquisa Agropecuária Brasileira, 19: 615-622.

Fernández, F.; Sharkey, M. (Eds.). 2006. Introducción a los Hymenoptera de la Región Neotropical. Sociedad Colombiana de Entomología y Universidad Nacional de Colombia, Bogotá, 894p.

Ferreira, F.Z.; Silveira, L.C.P.; Haro, M.M. 2013. Families of Hymenoptera parasitoids in organic coffee cultivation in Santo Antonio do Amparo, MG, Brazil. Coffee Science, 8: 1-4.

Filho, A.B.; da Silva, E.M. 1988. Observaçōes sobre o parasitismo de Neodusmetia sangwani sobre a cochonilha (Antonina graminis). Pesquisa Agropecuária Brasileira, 23: 329-331.

Fraser, S.E.M.; Dythan, C.; Mayhew, P.J. 2008. The effectiveness and optimal use of Malaise traps for monitoring parasitoid wasps. Insect Conservation and Diversity, 1: 22-31.

Garcia, M.V.B.; Tavares, A.M.; Krug, C.; Gomes, F.B. 2016. Guaraná. In: Silva, N.M.; Adaime, R.; Zucchi, R.A. (Eds.). Pragas Agrícolas e Florestais na Amazônia. Embrapa, Brasília, p.190-199.

Gotelli, N.J.; Ellisson, A.M. 2004. A Primer of Ecological Statistics. Sinauer Associates, Inc. Sunderland, 614p.

Goulet, H.; Huber, J.T. 1993. Hymenoptera of the World: an Identification Guide to Families. Centre for Land and Biological Resources Research, Ottawa, 668p.

Hyvönen, T.; Ketoja, E.; Salonen, J.; Jalli, H.; Tiainen, J. 2003. Weed species diversity and community composition in organic and conventional cropping of spring cereals. Agriculture, Ecosystems and Environment, 97: 131-149.

Klesener, D.F.; Santos, R.S.S. Menezes Jr., A.O. 2013. Diversidade e Atividade de Voo de Himenópteros Parasitoides em Pomar de Macieira em Vacaria, RS. EntomoBrasilis, 6: 108-112.

Kremen, C. 2005. Managing ecosystem services: what do we need to know about their ecology? Ecology Letters, 8: 468-479.

Kruess, A.; Tscharntke, T. 2000. Species richness and parasitism in a fragmented landscape: Experiments and field studies with insects on Vicia sepuim. Oecologia, 122: 129-137.

Krug, C.; Garcia, M.V.B.; Gomes, F.B. 2015. A scientific note on new insights in the pollination of guarana (Paullinia cupana var. sorbilis). Apidologie (Celle), 46: 164-166.

Landis, D.A.; Wratten, S.D.; Gurr, G.M. 2000. Habitat management to conserve natural enemies of arthropod pests in agriculture. Annual Review of Entomology, 45: 175-201.
Lara, R.I.R.; Fernandes, D.R.R.; Versuti, D.R. Tango, M. F.A.; Perioto, N.W. 2015. Sampling and Diversity of Hymenoptera (Insecta) in an Orange Orchard/Brazilian Savannah Fragment Interface. EntomoBrasilis, 8: 51-57.

Loomans, A.J.M. 2006. Exploration for hymenopterous parasitoids of thrips. Bulletin of Insectology, 59: 69-83.

Longino, J.T.; Coddington, J.; Colwell, K. 2002. The ant fauna of a tropical rain forest: estimating species richness three different ways. Ecology, 83: 689-702.

Mantel, N. 1967. The detection of disease clustering and a generalized regression approach. Cancer Research, 27: 209-220.

Masner, L.T.; Aryas-Pena, T.M. 2006. Família Platygastridae. In: Fernández, F.; Sharkey, M.J. (Ed.). Introdución a los Hymenoptera de la Región Neotropical. Sociedad Colombiana de Entomología and Universidad Nacional de Colombia, Bogotá, p.771-774.

Mazón, M. 2016. Taking shortcuts to measure species diversity: parasitoid Hymenoptera subfamilies as surrogates of species richness. Biodiversity and Conservation, 25: 67-76.

Mazón, M.; Bordera, S. 2008. Effectiveness of two sampling methods used for collecting Ichneumonidae (Hymenoptera) in the Cabañeros National Park (Spain). European Journal of Entomology, 105: 879-888.

Minchin, P.R. 1987. An evaluation of the relative robustness of techniques for ecological ordination. Vegetatio, 69: 89-107.

Nakayama, K.; Azevedo, C.O.; Valverde, M.J.O.; Neves, F.S.; Sperber, C.F. 2008. Sampling parasitoid wasps (Insecta, Hymenoptera) in cacao agroforestry systems. Studies on Neotropical Fauna and Environment, 43: 217-226.

Noyes, J.S. 1980. A review of the genera of Neotropical Encyrtidae (Hymenoptera: Chalcidoidea). Bulletin of the British Museum, Natural History, Entomology, 41: 107-253.

Noyes, J.S. 1989. A study of five methods of sampling Hymenoptera (Insecta) in a tropical rainforest, with special reference to the Parasitica. Journal of Natural History, 23: 285-298.

Oksanen, J.; Blanchet, F.G.; Friendly, M.; Kindt, R.; Legendre, P.; McGlinn, D.; et al. 2016. Vegan: Community Ecology Package. $\mathrm{R}$ package version 2.4-0. (https://CRAN.R-project.org/ package=vegan). Accessed on 18 Aug 2016.

Pereira, J.C.R. (Ed.). 2005. Cultura do Guaranazeiro no Amazonas. 4th ed. Embrapa Amazônia Ocidental, Manaus, 40p.

Perioto, N.W.; Lara, R.I.R.; Santos, J.C.C.; Selegatto, A. 2002a. Himenópteros parasitoides (Insecta: Hymenoptera) coletados em cultura de algodão (Gossypium hirsutum L.) (Malvaceae), no município de Ribeirão Preto, SP, Brasil. Revista Brasileira de Entomologia, 46: 165-16.

Perioto, N.W.; Lara, R.I. R.; Santos, J.C.C.; Silva. T. C. 2002b. Himenópteros parasitóides (Insecta, Hymenoptera) coletados em cultura de soja (Glycine max (L.)) Merril (Fabaceae), no município de Nuporanga, SP, Brasil. Revista Brasileira de Entomologia, 46: 185-187.

Perioto, N.W.; Lara, R.I.R.; Selegatto, A.; Luciano, E.S. 2004. Himenópteros parasitoides (Insecta, Hymenoptera) coletados em cultura de café Coffea arabica L. (Rubiaceae) em Ribeirão Preto, SP, Brasil. Arquivos do Instituto Biológico, 71: 41-44. 
Pfiffner, L.; Luka, H. 2000. Overwintering of arthropods in soils of arable fields and adjacent semi-natural habitats. Agriculture, Ecosystems and Environmental, 78: 215-222.

Pinheiro-Machado, C.; Alves-dos-Santos, I.; Imperatriz-Fonseca, V.L.; Kleinert, A.D. M.P.; Silveira, F.A. 2002. Brazilian bee surveys: state of knowledge, conservation and sustainable use. In: Kevan, P.; Imperatriz-Fonseca, V.L. (Ed.). Pollinating Bees, The Conservation Link Between Agriculture and Nature. Ministério do Meio Ambiente, Brasília, p.115-129.

Puech, C.; Baudry, J.; Joannon, A.; Poggi, S.; Aviron, S. 2014. Organic vs. conventional farming dichotomy: Does it make sense for natural enemies? Agriculture, Ecosystems and Environment, 194: 48-57.

R Development Core Team. 2016. R: A language and environment for statistical computing. R Foundation for Statistical Computing, Vienna, Austria. (http://www.R-project.org/). Accessed on 06 Aug 2016.

Roschewitz, I.; Gabriel, D.; Tscharntke, T.; Thies, C. 2005. The effects of landscape complexity on arable weed species diversity in organic and conventional farming. Journal of Applied Ecology, 42: 873-882.

Santos, J.H.R. 1976. Controle biológico de Antonina gramanis (Maskell, 1897) pela Neodusmetia sangwani (Rao, 1957) em Fortaleza no Estado do Ceará, Brasil. Anais da Sociedade Entomológica do Brasil, 5: 18-28.

Schultz, Q.S.; Valois, A.C.C. 1974. Estudos sobre o mecanismo de floração e frutificação do guaranazeiro. Boletim Técnico, IPAAO, 4: 35-36.

Sharkey, M.J. 2007. Phylogeny and classification of Hymenoptera. Zootaxa, 1668: 521-548.

Siemann, E. 1998. Experimental tests of effects of plant productivity and diversity on grassland arthropod diversity. Ecology, 79: 2057-2070.
Siemann, E.; Tilman, D.; Haarstad, J.; Ritchie, M. 1998. Experimental tests of the dependence of arthropod diversity on plant diversity. The American Naturalist, 152: 738-750.

Sperber, C.F.; Nakayama, K.; Valverde, M.J.; Neves, F.S. 2004. Tree species richness and density affects parasitoid diversity in cacao agroforestry. Basic and Applied Ecology, 5: 241-251.

Tavares, A.M.; García, M.V.B. 2009. Tripes do Guaranazeiro: Liothrips adisi zur Strassen, 1977 (Thysanoptera: Phlaeothripidae: Phlaeothripinae). Embrapa Amazônia Ocidental, Manaus, 47p.

Thies, C.; Tscharntke, T. 1999. Landscape structure and biological control in agroecosystems. Science, 285: 893-895.

Tilman, D.; Cassman, K.G.; Matson, P.A.; Naylor, R.; Polasky, S. 2002. Agricultural sustainability and intensive production practices. Nature, 418: 671-677.

Townes, H. 1972. A light-weight malaise trap. Entomological News, 83: 239-247.

Tscharntke, T.; Klein, A.M.; Kruess, A.; Steffan-Dewenter, I.; Thies, C. 2005. Landscape perspectives on agricultural intensification and biodiversity-ecosystem service management. Ecology Letters, 8: $857-874$.

Yandell, B.S. 1997. Practical Data Analysis for Designed Experiments. Chapman \& Hall/CRC Press, London/Cleveland, 440p.

Werling, B.P.; Meehan, T.D.; Graton, C.; Landis, D.A. 2011. Influence of habitat and landscape perenniality on insect natural enemies in three candidate biofuel crops. Biological Control, 59: 304-312.

Woltz, J.M.; Isaacs R.; Landis, D.A. 2012. Landscape structure and habitat management differentially influence insect natural enemies in agricultural landscape. Agriculture, Ecosystems and Environment, 152: 40-49.

RECEIVED: $22 / 02 / 2019$

ACCEPTED: $31 / 08 / 2019$

ASSOCIATE EDITOR: Eraldo R. Lima 
SUPPLEMENTARY MATERIAL (only available in the electronic version)

SCHOENINGER et atl. Diversity of parasitoid wasps in conventional and organic guarana (Paullinia cupana var. sorbilis) cultivation areas in the Brazilian Amazon
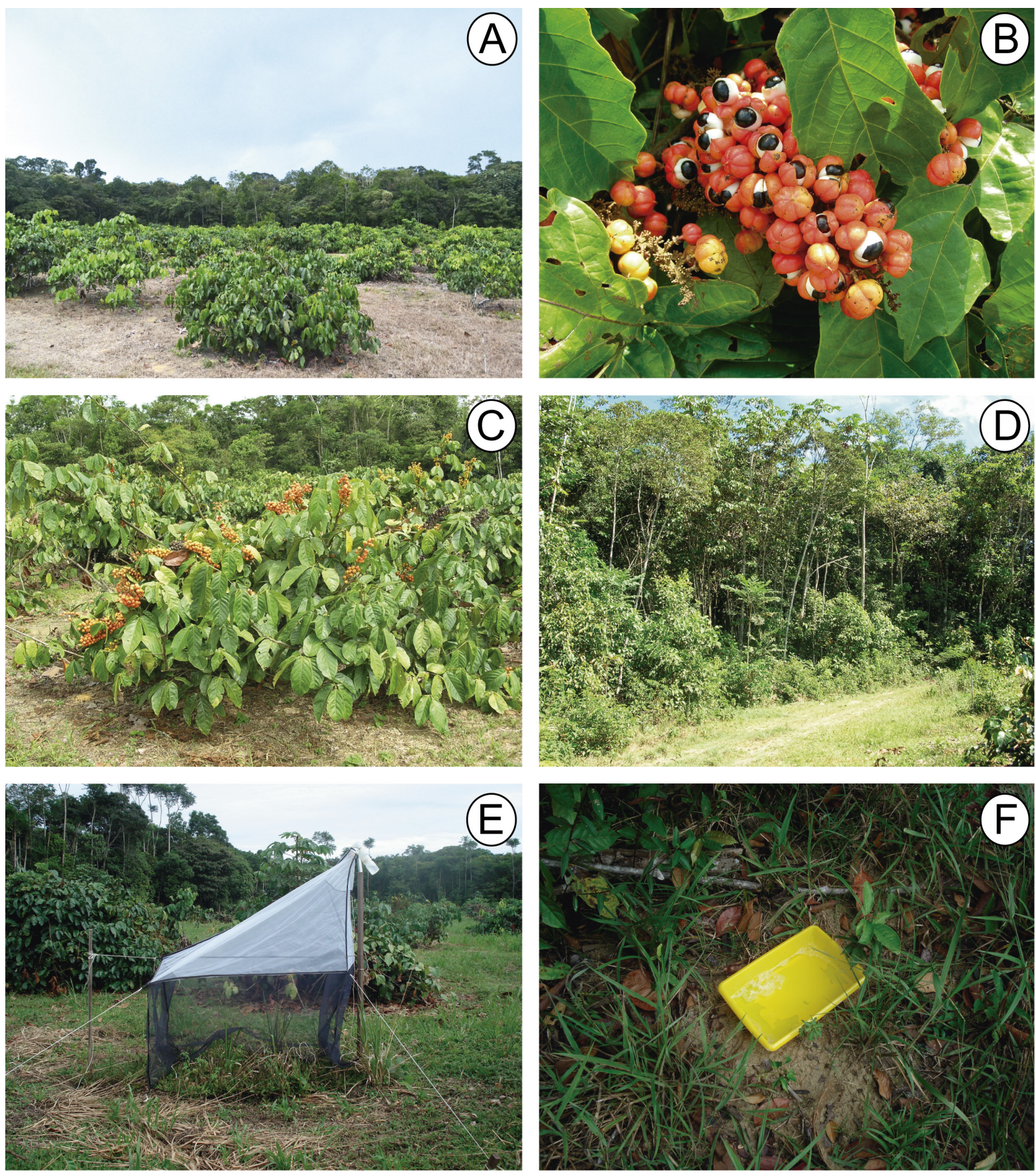

Figure S1. Images of the guarana plantations sampled in the study: conventional cultivation area (A); fructification of guarana (B); fruiting guarana plant in the organic cultivation area (C); adjacent forest and forest-crop edge in the organic plantation area (D); Malaise trap (E); Moericke trap (F). 